\title{
Synthesis and Antibacterial Activity of Novel Cyclic $\alpha$-Aminophsophonates
}

\author{
Ibrahim El Tantawy El Sayed*, Ghady Fathy and Abdullah A S Ahmed \\ Department of Chemistry, Egypt
}

*Corresponding author: Ibrahim El Tantawy El Sayed, Department of Chemistry, Faculty of Science, Menoufia University, Shebin

El-Kom, Egypt

\section{ARTICLE INFO}

Received: 幽 November 29, 2019

Published: 㓞December 06, 2019

Citation: Ibrahim El Tantawy El Sayed, Ghady Fathy, Abdullah A S Ahmed. Synthesis and Antibacterial Activity of Novel Cyclic $\alpha$-Aminophsophonates. Biomed J Sci \& Tech Res 23(4)-2019. BJSTR. MS.ID.003936.

\begin{abstract}
Synthesis of novel $\alpha$-aminophsophonates 4 and 7 was accomplished at room temperature with good yields by three one-pot reaction of glutaraldehyde 1 with various free diamines 2or 4-aminoquinoline 5 and triphenyl phosphite 3 or diphenyl phosphite 6 in acetonitrile as solvent and in presence of LiClO4 as a Lewis acid catalyst at room temperature. The unexpected cyclic $\alpha$-aminophosphates 4 and 7 were afforded by intramolecular cyclization as reported in schemes $2-4$. All newly synthesized cyclic $\alpha$-aminophsophonates were characterized by spectroscopic methods as MS, IR, $1 \mathrm{H}$ and 31P-NMR and affirmed the installation of 4 and 7. All synthesized compounds were screened for their in vitro antibacterial activity against series of Klebsiella pneumonia and $E$. coli revealing the highest antibacterial activity of $4 \mathrm{a}$ and $7 \mathrm{a}$ comparing to reference drug ciprofloxacin.
\end{abstract}

Keywords: Synthesis; Cyclic $\alpha$-Aminophsophonates; Glutaraldehyde; Diamines; Quinoline; Antibacterial Activity

\section{Introduction}

$\alpha$-Aminophosphonates I gained great interest of medicinal chemists due to their biological activities [1,2], metabolic stability and their weak toxicity towards mammalians. These organometallic compounds are phosphorus analogues of naturally occurring $\alpha$-amino acids II ( $c f$. Figure 1). The biological activity of $\alpha$-aminophosphonates was reported in literatures as anticancer $[3,4]$ and antibacterial [5]. Furthermore, these compounds are used as antifungal, anticancer, antiviral agents [6,7] and herbicides [8,9]. Therefore, $\alpha$-aminophosphonates considered a promising pharmacophore core in the fields of drug design and discovery [10-12]. Moreover, nitrogen containing heterocyclic compounds such quinolines III, received much attention due their wide pharmacological applications [13]. The enhancement and synergistic effect of the quinoline moiety by modification of side chain at ( $\mathrm{C} 4$ position) and/or with conjugation with other structural motifs [14,15]. For instance, hybridization of quinoline moiety with $\alpha$-aminophsophonates was proved significant synergistic effect on biological activity [16]. Based on above-mentioned, the aim of the work presented in this study is to synthesize some new $\alpha$-aminophosphonates bearing quinoline nucleus. Further aim is to screen the resulting hybrids as antibacterial agents against different bacterial strains. Moreover, correlate the structures with the biological activity.<smiles>[R][X]C([R])P(=O)([R]O[R])O[R]</smiles><smiles>[R]C(N)C(=O)O</smiles><smiles>c1ccc2ncccc2c1</smiles>

III

Figure 1: Structures of a -Aminophosphonates I, a -Amino acids II andquinoline III.

\section{Materials and Methods}

All ${ }^{1} \mathrm{H}-\mathrm{NMR}$ experiments (DMSO- $\mathrm{d}_{6}$ and $\mathrm{CDCl}_{3}$ ) were carried out with a $500 \mathrm{MHz}$ Jeol at El-Mansoura University in addition, some samples were performed with $400 \mathrm{MHz}$ Varian at the Main Chemical Warfare Laboratories, Egypt. Chemical shifts are reported in part per million (ppm) relative to the position respective to the solvent. 
The mass and IR spectroscopy spectra were performed at Al-Azahr and El-Mansoura University respectively, Egypt [17,18]. Melting points were recorded on Stuart scientific melting point apparatus and are uncorrected. Antimicrobial activity for all synthesized compounds was screened at National Organization for drug and Control Research, Egypt. All reactions were followed by thin layer chromatography (TLC) on kiesel gel F254 precoated plates (Merck). Starting materials, glutaraldehyde, 4,7-dichloroquinoline, amines, diphenyl phosphite and triphenyl phosphite were commercially available from sigma alderic. Solvents such as ethanol, acetonitrile, dichloromethane, hexane, dimethylformamide and diethyl ether were used without any further purification. All synthesized 4-aminoquinoline derivatives were carried out as reported in literature [19-21].

\section{Synthesis of $\alpha$-Aminophosphonate Derivatives Using Triphenyl Phosphites}

General Procedure for The Synthesis of $\boldsymbol{\alpha}$-Aminophosphonate Derivatives (4a-e): To solution of glutaraldehyde (0.24 $\mathrm{mL}, 2 \mathrm{mmol}$ ), diamines ( $2 \mathrm{mmol}$ ), triphenyl phosphite $(0.39 \mathrm{~mL}, 2 \mathrm{mmol})$ dissolved in acetonitrile $(5 \mathrm{~mL})$ Lewis acid catalyst $\mathrm{LiClO}_{4}(2.1 \mathrm{mg}, 10 \% \mathrm{~mol}$ ) was added. The reaction mixture was stirred at r.t and the completion of the reaction was monitored by TLC (48 hours). The formed precipitate was filtered off and dried to afford $\alpha$-aminophosphonates 5 in good yields.

Diphenyl ( $\alpha$-Aminopiperidin-2-yl) Phosphonate 4a: Yield $=(0.26 \mathrm{~g}, 40 \%)$, reddish brown viscous oil, IR $(\mathrm{KBr}) \mathrm{cm}^{-1} \mathrm{v}: 3340$ $\left(\mathrm{NH}_{2}\right), 3070(=\mathrm{CH}), 2955,2861(-\mathrm{CH}), 1629$ (C=C, aromatic), 1230 $(\mathrm{P}=0), 759$ (POC). EIMS m/z: $\left(\mathrm{C}_{17} \mathrm{H}_{21} \mathrm{~N}_{2} \mathrm{O}_{3} \mathrm{P}\right)$ calcd.: $332.33\left[\mathrm{M}^{+}\right]$, found: $332.26 .{ }^{1} \mathrm{H}-\mathrm{NMR}$ (DMSO- $\mathrm{d}_{6}, 400 \mathrm{MHz}$ ) ppm $\delta: 1.13(\mathrm{~m}, 2 \mathrm{H}$, $\mathrm{CH}_{2}$ ), 2.76 (br.m, 4H, 2CH${ }_{2}$ ), $3.58\left(\mathrm{~m}, 2 \mathrm{H}, \mathrm{N}-\mathrm{CH}_{2}\right.$ ), 6.02 (s, 1H, CHP), 6.74-7.46 (m, 10H, Ar-H). ${ }^{31}$ P-NMR (DMSO d $\left.{ }_{6}, 400 \mathrm{MHz}\right) \delta:-17.17$ ppm

Diphenyl ( $\alpha$-(2-Aminoethyl) Piperidin-2-yl) Phosphonate 4b: Yield $=(0.38 \mathrm{~g}, 54 \%)$, reddish brown viscous oil, $\mathrm{IR}(\mathrm{KBr}) \mathrm{cm}^{-1}$ v: $3430\left(\mathrm{NH}_{2}\right), 3067$ (=CH), 2961, 2875 (-CH), 1629 (C=C, aromatic), 1240 (P=0), 762 (POC). EIMS m/z: $\left(\mathrm{C}_{19} \mathrm{H}_{25} \mathrm{~N}_{2} \mathrm{O}_{3} \mathrm{P}\right)$, calcd.: 360.39 $\left[\mathrm{M}^{+}\right]$, found: 360.02. ${ }^{1} \mathrm{H}-\mathrm{NMR}$ (DMSO- $\left.\mathrm{d}_{6}, 400 \mathrm{MHz}\right) \mathrm{ppm} \delta: 1.13(\mathrm{~m}$, $2 \mathrm{H}, \mathrm{CH}_{2}$ ), 2.49 (br.s, $2 \mathrm{H}, \mathrm{CH}_{2}$ ), 2.71 (br.m, $4 \mathrm{H}, 2 \mathrm{CH}_{2}$ ), $3.71(\mathrm{~m}, 4 \mathrm{H}, 2 \mathrm{~N}-$ $\mathrm{CH}_{2}$ ), 6.00 (s, 1H, C$\left.-\mathrm{P}\right), 6.75-7.25$ (m, 10H, Ar-H).

Diphenyl ( $\alpha$-(3-Aminopropyl) Piperidin-2-yl) Phosphonate 4c: Yield $=(0.32 \mathrm{~g}, 43 \%)$, reddish brown viscous oil, IR $(\mathrm{KBr}) \mathrm{cm}^{-1}$ v: $3430\left(\mathrm{NH}_{2}\right), 3067$ (=CH), $2923(-\mathrm{CH}), 1646$ (C=C, aromatic), 1367 $(\mathrm{P}=0), 774$ (POC). EIMS m/z: $\left(\mathrm{C}_{20} \mathrm{H}_{27} \mathrm{~N}_{2} \mathrm{O}_{3} \mathrm{P}\right)$ Calcd.: $374.41\left[\mathrm{M}^{+}\right]$, found: 371.41. ${ }^{1} \mathrm{H}-\mathrm{NMR}$ (DMSO $\left.\mathrm{d}_{6}, 400 \mathrm{MHz}\right) \mathrm{ppm} \delta: 1.16(\mathrm{~m}, 2 \mathrm{H}$, $\left.\mathrm{CH}_{2}\right), 1.50\left(\mathrm{~m}, 2 \mathrm{H}, \mathrm{CH}_{2}\right), 2.59\left(\mathrm{~m}, 4 \mathrm{H}, 2 \mathrm{CH}_{2}\right), 2.72\left(\mathrm{~m}, 4 \mathrm{H}, 2 \mathrm{CH}_{2}\right), 3.79$ (m, 2H, N-CH ${ }_{2}$ ) 6.07 (s, 1H, $\left.\mathrm{C} \underline{\mathrm{H}}-\mathrm{P}\right), 6.73-7.33$ (m, 10H, Ar-H).

Diphenyl ( $\alpha$-(3-Aminophenyl) Piperidin-2-yl) Phosphonate 4d: Yield $=(0.38 \mathrm{~g}, 47 \%)$, brown viscous oil, $\mathrm{IR}(\mathrm{KBr}) \mathrm{cm}^{-1} \mathrm{v}: 3432$ $\left(\mathrm{NH}_{2}\right), 3100(=\mathrm{CH}), 2925(-\mathrm{CH}), 1626(\mathrm{C}=\mathrm{C}$, aromatic), $1291(\mathrm{P}=0)$,
758 (POC). EIMS m/z: $\left(\mathrm{C}_{23} \mathrm{H}_{25} \mathrm{~N}_{2} \mathrm{O}_{3} \mathrm{P}\right)$ calcd.: 408.43 [M+], found: 408.53. ${ }^{1} \mathrm{H}-\mathrm{NMR}$ (DMSO d ${ }_{6}, 400 \mathrm{MHz}$ ) ppm $\delta: 1.54\left(\mathrm{~m}, 2 \mathrm{H}, \mathrm{CH}_{2}\right.$ ), 2.23 (br.m, 2H, $\mathrm{CH}_{2}$ ), 3.96 (br.m, 2H, $\mathrm{CH}_{2}$ ), 4.30 (br.m, 2H, $\mathrm{CH}_{2}$ ), 6.07 (s, 1H, C$-\mathrm{P}$ ), 6.73-7.46 (m, 14H, Ar-H) 9.05(br.s, 2H, $\mathrm{NH}_{2}$ ).

Diphenyl ( $\alpha$-(4-Aminophenyl) Piperidin-2-yl) Phosphonate 4e: Yield $=(0.5 \mathrm{~g}, 61 \%)$, black viscous oil, $\mathrm{IR}(\mathrm{KBr}) \mathrm{cm}^{-1}$ v: 3370 $\left(\mathrm{NH}_{2}\right), 3071(=\mathrm{CH}), 2926(-\mathrm{CH}), 1594(\mathrm{C}=\mathrm{C}$, aromatic), $1226(\mathrm{P}=0)$, 755 (POC). EIMS m/z: $\left(\mathrm{C}_{23} \mathrm{H}_{25} \mathrm{~N}_{2} \mathrm{O}_{3} \mathrm{P}\right)$ calcd.: 408.43 [M+], found: 408.88. ${ }^{1} \mathrm{H}-\mathrm{NMR}$ (DMSO d ${ }_{6}, 400 \mathrm{MHz}$ ) ppm $\delta: 1.04\left(\mathrm{~m}, 4 \mathrm{H}, 2 \mathrm{CH}_{2}\right.$ ),

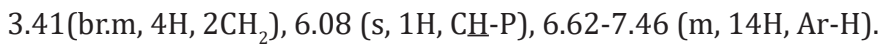

General Procedures for Synthesis of $\alpha$-Aminophosphonate Derivatives Bearing Quinoline Moiety: (7a-e): Glutaraldehyde (0.24 $\mathrm{mL}, 2 \mathrm{mmol})$, diamines (2 mmol) and diphenyl phosphite $(0.37 \mathrm{~mL}, 2 \mathrm{mmol})$ were dissolved in acetonitrile $(5 \mathrm{~mL})$ in presence of $\mathrm{LiClO}_{4}$ as Lewis acid catalyst (2.1 mg, 10\% mol.) was added. The reaction mixture was stirred at r.t and the completion of the reaction was monitored by TLC ( 48 hours). The desired product was filtered off and dried to afford $\alpha$-aminophosphonates $\mathbf{9}$ with goodyields.

Diphenyl( $\alpha$-((7-Chloroquinolin-4-yl) Amino) Piperidin-2yl) Phosphonate 7a: Yield $=(0.44 \mathrm{~g}, 45 \%)$, off white solids, m.p = 140-142 ${ }^{\circ} \mathrm{C}$, IR (KBr) cm-1 v: $3445(\mathrm{NH}), 3027$ (=CH), $2921(-\mathrm{CH})$, 1602 (C=C, aromatic), $1546(\mathrm{C}=\mathrm{N}), 1207$ ( $\mathrm{P}=0), 764$ (POC). EIMS $\mathrm{m} / \mathrm{z}:\left(\mathrm{C}_{26} \mathrm{H}_{25} \mathrm{ClN}_{3} \mathrm{O}_{3} \mathrm{P}\right)$ calcd.: 493.92[M+], found: 493.55. ${ }^{1} \mathrm{H}-\mathrm{NMR}$ (DMSO d 6 , 400MHz) ppm $\delta: 3.39$ (br.m, 8H, 4CH $\mathrm{CH}_{2}$ ), 6.10 (s, $1 \mathrm{H}, \mathrm{C} \underline{\mathrm{H}}-$ P), 6.71-8.00 (m, 14H, Ar-H), $8.52\left(\mathrm{~s}, 1 \mathrm{H}, \mathrm{CH}=\mathrm{N}_{\mathrm{Ar}}\right)$.

Diphenyl( $\alpha$-(2-((7-Chloroquinolin-4-yl) Amino) Ethyl) Piperidin-2- yl) Phosphonate 7b: Yield $=(0.5 \mathrm{~g}, 48 \%)$, brown solids, m.p $=112-114{ }^{\circ} \mathrm{C}$, IR $(\mathrm{KBr}) v \mathrm{~cm}^{-1}: 3244(\mathrm{NH})$, 3035(=CH),2930 (-CH), 1612 (C=C,aromatic), 1554 (C=N) 1215 $(\mathrm{P}=0), 763$ (POC). EIMS m/z: $\left(\mathrm{C}_{28} \mathrm{H}_{29} \mathrm{ClN}_{3} \mathrm{O}_{3} \mathrm{P}\right)$ calcd.: $521.97\left[\mathrm{M}^{+}\right]$, found: 521.79. ${ }^{1} \mathrm{H}-\mathrm{NMR}$ (DMSO $\mathrm{d}_{6}, 500 \mathrm{MHz}$ ): $\delta$ ppm: 1.20 (br.s,

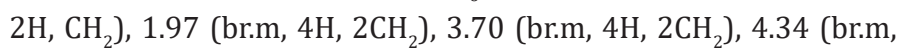
$2 \mathrm{H}, \mathrm{CH}_{2}$ ) 6.08 (s, 1H, Cㅍ-P), 6.73-8.23(m, 14H, Ar-H), 8.88 (s, 1H, $\mathrm{CH}=\mathrm{N}_{\mathrm{Ar}}$ ).

Diphenyl( $\alpha$-(3-((7-Chloroquinolin-4-yl) Amino) Propyl) Piperidin-2-yl) Phosphonate 7c: Yield $=(0.46 \mathrm{~g}, 43 \%)$, pale yellow solids, m.p = 106-110 ${ }^{\circ} \mathrm{C}$, IR (KBr) $\mathrm{v} \mathrm{cm}^{-1}: 3421,3247(\mathrm{NH})$, 3109 (=CH), 2937 (-CH), 1615 (C=C, aromatic), 1580 (C=N) 1205 $(\mathrm{P}=0), 763$ (POC). EIMS m/z: $\left(\mathrm{C}_{29} \mathrm{H}_{31} \mathrm{ClN}_{3} \mathrm{O}_{3} \mathrm{P}\right)$ calcd.: $536.00\left[\mathrm{M}^{+}\right]$, found: 538.18. ${ }^{1} \mathrm{H}-\mathrm{NMR}\left(\mathrm{CDCl}_{3}, 400 \mathrm{MHz}\right) \mathrm{ppm} \delta: 1.25$ (br.s, $\left.2 \mathrm{H}, \mathrm{CH}_{2}\right)$,

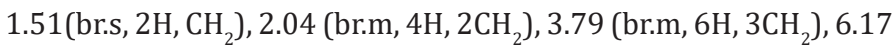
(s, 1H, Cㅍ-P), 6.83-8.03 (m, 14H, Ar-H), $8.42\left(\mathrm{~d}, 1 \mathrm{H}, \mathrm{CH}=\mathrm{N}_{\mathrm{Ar}} \mathrm{J}=8 \mathrm{~Hz}\right.$ ), 9.22 (br.s, $1 \mathrm{H}, \mathrm{NH}$ ). ${ }^{31} \mathrm{P}-\mathrm{NMR}$ (DMSO $\left.\mathrm{d}_{6}, 500 \mathrm{MHz}\right) \delta$ ppm: 0.310, -1.709 .

Diphenyl ( $\alpha$-(3-((7-Chloroquinolin-4-yl) Amino) Phenyl) Piperidin-2-yl) Phosphonate 7d: Yield $=(0.47 \mathrm{~g}, 42 \%)$, black solids, m.p $=<300{ }^{\circ} \mathrm{C}$, IR (KBr) $v \mathrm{~cm}^{-1}: 3434(\mathrm{NH}), 3050$ (=CH), 2926 (-CH), 1597 (C=C, aromatic), $1537(\mathrm{C}=\mathrm{N}) 1365(\mathrm{P}=\mathrm{O}), 700$ (POC). EIMS m/z: $\left(\mathrm{C}_{32} \mathrm{H}_{29} \mathrm{ClN}_{3} \mathrm{O}_{3} \mathrm{P}\right)$ calcd.: $570.02\left[\mathrm{M}^{+}\right]$, found: 570.66 . 
${ }^{1} \mathrm{H}-\mathrm{NMR}$ (DMSO d ${ }_{6}, 400 \mathrm{MHz}$ ): $\delta$ ppm 3.72 (br.m, 8H, 4CH $\mathrm{CH}_{2}$ ), 6.05 (s, $1 \mathrm{H}, \mathrm{CH}-\mathrm{P}$ ), 6.73-8.05 (m, 18H, Ar-H), 8.62 (s, 1H, CH=N $\mathrm{Ar}_{\mathrm{Ar}}$ ) 9.34 (br.s, $1 \mathrm{H}, \mathrm{NH})$.

Diphenyl( $\alpha$-(4-((7-Chloroquinolin-4-yl) Amino) Phenyl) Piperidin-2-yl) Phosphonate 7e: Yield (0.58g, 51\%), pale yellow solids, m.p $=265-267^{\circ} \mathrm{C}$, IR $(\mathrm{KBr}) \mathrm{cm}^{-1} \mathrm{v}: 3432,3320(\mathrm{NH}), 3068$ (=CH), $2903(-\mathrm{CH}), 1620(\mathrm{C}=\mathrm{C}$, aromatic), $1542(\mathrm{C}=\mathrm{N}), 1230(\mathrm{P}=0)$, 792 (POC). EIMS m/z: $\left(\mathrm{C}_{32} \mathrm{H}_{29} \mathrm{ClN}_{3} \mathrm{O}_{3} \mathrm{P}\right)$ calcd.: $570.02\left[\mathrm{M}^{+}\right]$, found: 570.48. ${ }^{1} \mathrm{H}-\mathrm{NMR}$ (DMSO d $\left.{ }_{6}, 400 \mathrm{MHz}\right) \mathrm{ppm} \delta: 1.16\left(\mathrm{~m}, 2 \mathrm{H}, \mathrm{CH}_{2}\right.$ ), 3.05 (br.m, 6H, 3CH $\mathrm{CH}_{2}$ ) 5.91 (s, 1H, Cㅍ-P), 6.54-8.38 (m, 19H, Ar-H), 8.59 (d, $1 \mathrm{H}, \mathrm{CH}=\mathrm{N}_{\mathrm{Ar}} J=8 \mathrm{~Hz}$ ), 10.20 (br.s, $1 \mathrm{H}, \mathrm{NH}$ ).

\section{Biological Screening}

\section{Bacterial Strains}

The antibacterial activity of different chemical compounds was tested against a set of E.coli ATCC 11229, Staphylococcus aureus ATCC 25923 and human MDR pathogenic clinical strains of Klebsiella pneumonia (Kp1, Kp5, Kp8 and Kp9) [14], and E. coli (E13, E15, E16 and E17) (unpublished data), and Staphylococcus aureus (SA4) (unpublished data) which were collected from Egyptian hospitals. Bacterial strains were recovered by culturing overnight at $37^{\circ} \mathrm{C}$ in Nutrient agar media (Oxoid, UK).

\section{Compounds Preparation for Antimicrobial Activity}

Compounds were dissolved in Dimethyl sulfoxide (DMSO), and then a final concentration of $100 \mathrm{mg} / \mathrm{ml}$ was prepared using sterile distilled water. Control DMSO was used to check the effect of solvent on the growth of microorganisms.

\section{Agar Well Diffusion Method}

A volume of $100 \mu \mathrm{l}$ bacterial suspension $\left(10^{6} \mathrm{CFU} / \mathrm{ml}\right)$ was spread on Müller-Hinton agar (Oxoid, UK). Wells were made on agar plates using sterile cork borer, and then $100 \mu \mathrm{l}$ of each prepared compound was introduced into appropriately marked wells, then plates were incubated for $24 \mathrm{~h}$ at $37^{\circ} \mathrm{C}$. DMSO was taken as a negative control. Antibacterial activity was evaluated by measuring the diameter of the inhibition zone in millimeters for each tested organism compared with the negative control [15].

\section{Result and Discussion}

\section{Chemistry}

A newly synthesized compounds of cyclic $\alpha$-aminophsophonates were performed by three one pot reaction of glutaraldehyde $1(0.24$ $\mathrm{mL}, 2 \mathrm{mmol})$, with various diamines $2(2 \mathrm{mmol})$ and triphenyl phosphite $3(0.39 \mathrm{~mL}, 2 \mathrm{mmol})$ in presence of $\left(\mathrm{LiClO}_{4}\right)$ in acetonitrile with equal molar ratio (1:1:1) to afford 5 in good yields as shown in scheme 1. In structure characterization of 5 , the IR spectra showed the absorption bands of $\left(\mathrm{NH}_{2}\right)$ ranging from 3432 to $3291 \mathrm{~cm}^{-1}$ and $(\mathrm{P}=0)$ from 1367 to $1226 \mathrm{~cm}^{-1}$. The ${ }^{1} \mathrm{H}-\mathrm{NMR}$ spectra showed the chemical shift of ( $\mathrm{C} \underline{\mathrm{H}}-\mathrm{P})$ as singlet peak ranging from $\delta: 6.00$ to 6.08 ppm which affirmed the formation of $\alpha$-aminophosphonate. It is noticeable that the absence of the aldehydic group (CHO) in ${ }^{1} \mathrm{H}-\mathrm{NMR}$ confirmed the formation of cyclic $\alpha$-aminophosphonates through intra molecular cyclization followed by water elimination $[17,18]$. The EI mass spectra confirmed the formation of 5 throughout the coincidence of the molecular ion peak with expected mass.

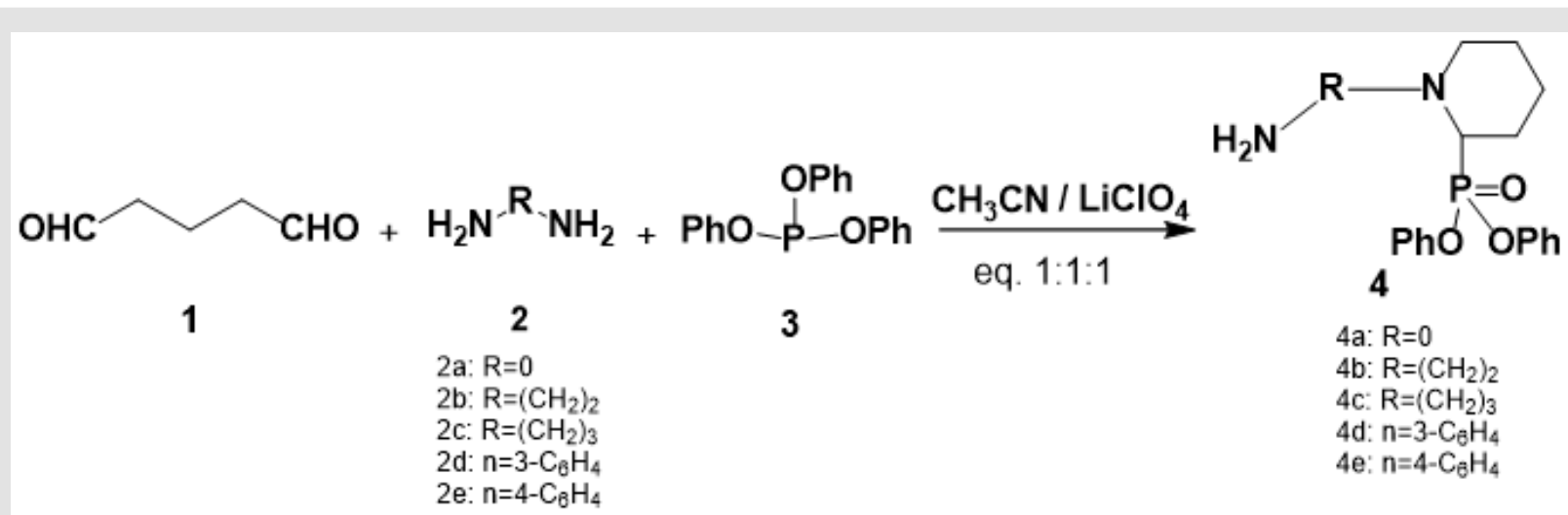

Scheme 1: Synthesis of a-aminophosphonate.

The recommended mechanism for preparation of cyclic $\alpha$-aminophosphonates using $\mathrm{LiClO}_{4}$ as a catalyst illustrated in Scheme 2, the reaction starts with activation of carbonyl group of glutaraldehyde by Lewis acid catalyst $\left(\mathrm{LiClO}_{4}\right)$ followed by condensation of the carbonyl group of the starting dialdehyde with primary amines to afford the Schiff base B. Then the nitrogen of Schiff base that is formed in the first step of $\alpha$-aminophosphonates formation donates a pair of electron to make a coordinante bond with $\mathrm{LiClO}_{4}$. This makes nitrogen positively charged which induces partial positive charge on $\mathrm{sp}^{2}$ carbon followed by nucleophilic attack of nitrogen of Schiff base on carbon atom of the other carbonyl group of glutaraldehyde. Then the free pair of electrons of phosphorus attacks to the partially positively charged carbon B followed by elimination of phenol $\mathrm{C}$ and afford cyclic $\alpha$ - aminophosphonates as depicted in Scheme 3. Synthesis of novel compounds of cyclic $\alpha$-aminophsophonate bearing quinoline moiety was accomplished by three one pot reaction of glutaraldehyde $1(0.24 \mathrm{~mL}, 2 \mathrm{mmol})$, 4-aminoquinoline derivatives 6 ( $2 \mathrm{mmol}$ )and diphenyl phosphite 7 
$(0.37 \mathrm{~mL}, 2 \mathrm{mmol})$ in presence of Lewis acid catalyst $\left(\mathrm{LiClO}_{4}\right)$ and acetonitrile with equal molar ratios (1:1:1) to get the desired product with good yields.

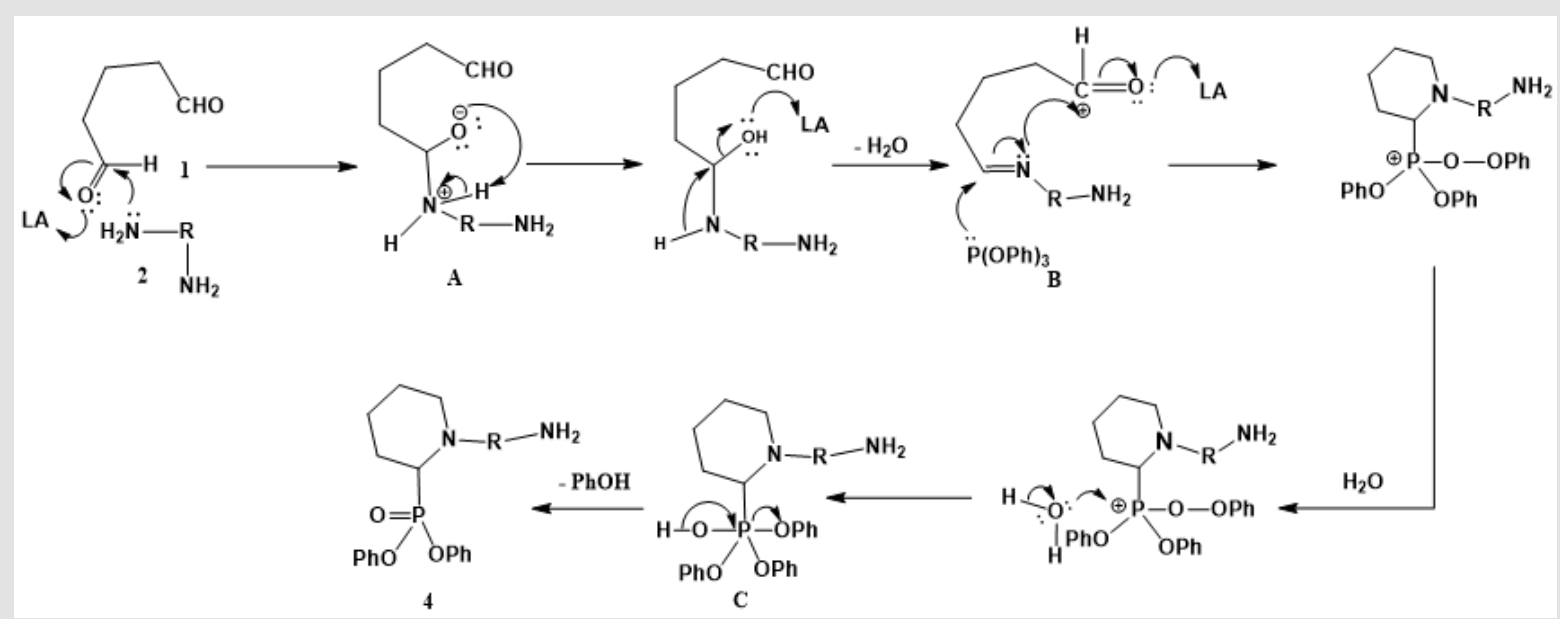

Scheme 2: Suggested mechanism of a-aminophsophonate.<smiles>[R]Nc1cc[nH+]c2cc(Cl)ccc12</smiles>

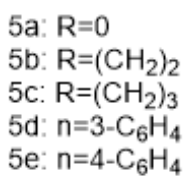

6<smiles>[R]Nc1c(N([2H])P(=O)(O)O)n(C)c2cc(Cl)ccc12</smiles>

7a: $R=0$

7b: $\mathrm{R}=\left(\mathrm{CH}_{2}\right)_{2}$

7c: $\mathrm{R}=\left(\mathrm{CH}_{2}\right)_{3}$

7d: $\mathrm{n}=3-\mathrm{C}_{6} \mathrm{H}_{4}$

7e: $n=4-\mathrm{C}_{6} \mathrm{H}_{4}$

Scheme 3: Synthesis of a-aminophsophonate bearing 4.7 dichloroquinoline.

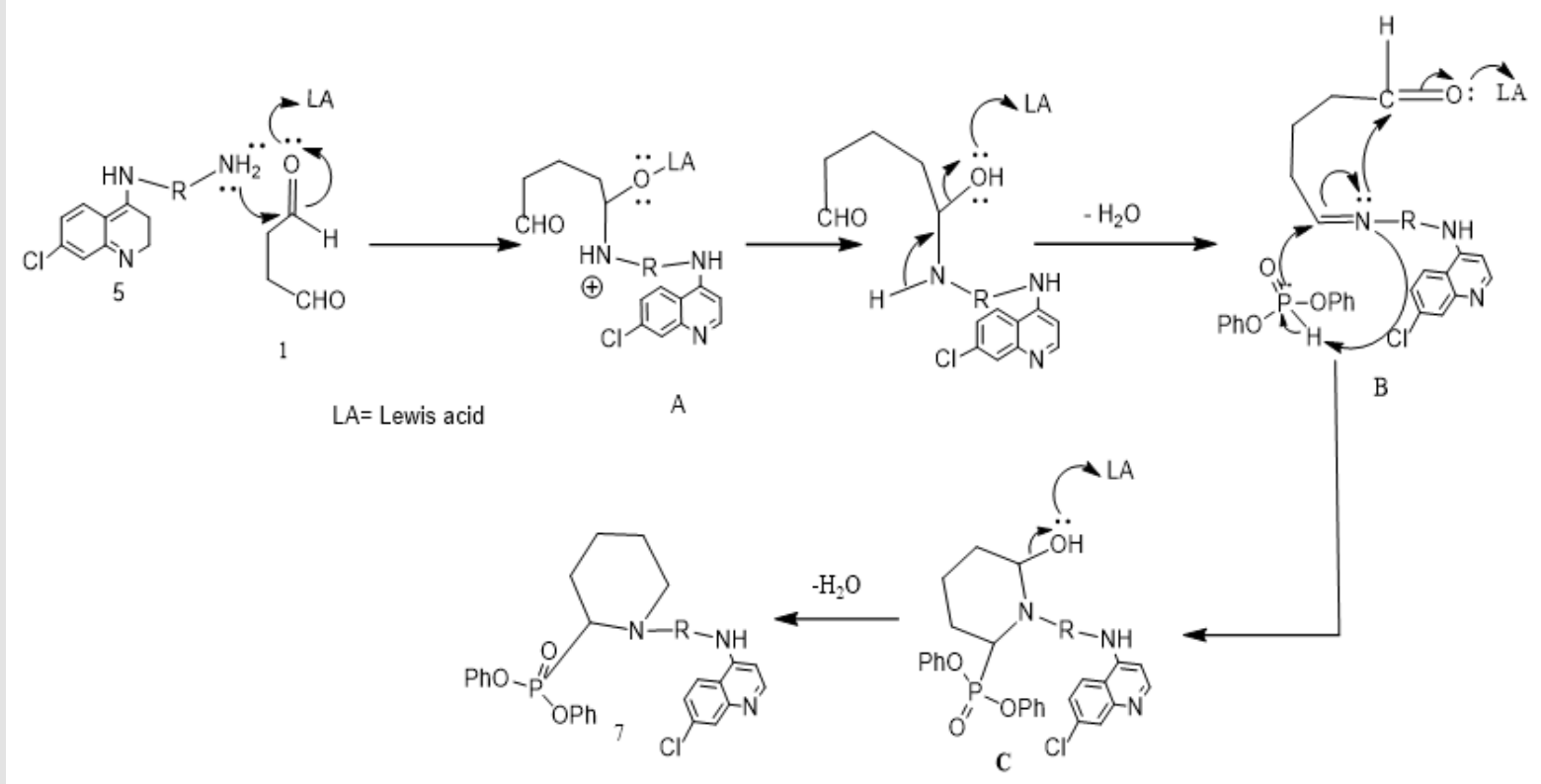

Scheme 4: A plausible mechanism of a-aminophsophonate bearing 4.7 dichloroquinoline. 
In the structure elucidation of installation of 7, the IR spectra of synthesized compounds showed the absorption bands of $\left(\mathrm{NH}_{2}\right)$ ranging from 3432 to $3291 \mathrm{~cm}^{-1}$ and $(\mathrm{P}=0)$ from 1365 to $1205 \mathrm{~cm}$ 1. The ${ }^{1} \mathrm{H}$-NMR spectra showed the chemical shift of ( $\mathrm{C}$-P) as singlet peak ranging from $\delta: 5.91$ to $6.17 \mathrm{ppm}$ which confirmed the formation of $\alpha$-aminophosphonate. While the aromatic $(\mathrm{C} \underline{\mathrm{H}}=\mathrm{N})$ of quinoline moiety was reported ranging from 8.52 to $8.88 \mathrm{ppm}$. The absence of the aldehydic group (CHO) in ${ }^{1} \mathrm{H}-\mathrm{NMR}$ confirmed the formation of cyclic $\alpha$-aminophosphonates through intra molecular cyclization followed by water elimination. The EI mass spectrum affirmed the formation of 7 throughout the coincidence of the molecular ion peak with expected mass.A proposed mechanism of formation of 7 was established. A plausible mechanism for preparation of $\alpha$-aminophosphonates using $\mathrm{LiClO}_{4}$ as a catalyst showed in Scheme 4. First, the activation of carbonyl group of glutaraldehyde was achieved by Lewis acid catalyst, $\mathrm{LiClO}_{4}$ followed by condensation of the carbonyl group with derivatives of 4-aminoquinoline 5 to form the Schiff base B. Then the free pair of electron on nitrogen of Schiff base attacked the partially positive carbon of the other carbonyl group of glutaraldehyde, which was activated by $\mathrm{LiClO}_{4}$, followed nucleophilic attack of phosphorus to the carbon of imine double bond to afford the target compound 7.

\section{Biological Evaluation}

In vitro, two groups of synthetic chemical compounds, cyclic $\alpha$-amino phosphonate using tri phenylphosphiteand cyclic $\alpha$-amino phosphonate bearing quinolone moiety, were tested against MDR strains of E.coli and K. pneumonia that already resistant to ciprofloxacin [17], Staphylococcus aureus ATCC25923, MRSA S. aureus, and finally clinical Candida albicans using well diffusion method and the data analyzed as recommended by CLSI [18]. The cyclic $\alpha$-amino phosphonate using tri phenylphosphite compounds showed various antimicrobial activities against tested microorganisms, where diphenyl (1-aminopiperidin-2-yl) phosphonate ( $5 \mathrm{a}$ ) was observed to record a broad-spectrum activity (Table 1). MDR E. coli 17 and K. pneumonia (with gyrase mutation at codon Asp 83 and Ser 87) were the most sensitive among the other tested bacteria. Based on our data, it has been observed that the substitution with other diamines as ethylene diamine, 1.3 di amino propane, phenylene diamine at (meta-position phenyl ring), 1.4 phenylene diamine didn't exert the desired antimicrobial activity as compared with that have hydrazine diamine.

Table 1: Antimicrobial activity of cyclic a-amino phosphonate using tri phenylphosphite against tested microorganisms.

\begin{tabular}{|c|c|c|c|c|c|c|c|c|c|c|c|}
\hline \multirow{4}{*}{$\begin{array}{l}\text { Chemical } \\
\text { Formula }\end{array}$} & \multicolumn{11}{|c|}{ Bacterial Species (Inhibition zones $\mathrm{mm} \pm$ SD*) } \\
\hline & \multicolumn{9}{|c|}{ Gram-Negative Bacteria } & \multicolumn{2}{|c|}{ Gram-Positive bacteria } \\
\hline & \multicolumn{4}{|c|}{ CIP-Resistant E. Coli } & \multicolumn{4}{|c|}{ CIP-Resistant Klebsiella Pneumonia } & \multirow{2}{*}{$\begin{array}{l}\text { E. coli ATCC } \\
11229\end{array}$} & \multirow{2}{*}{$\begin{array}{l}\text { Staph. Aureus } \\
\text { ATCC } 25923\end{array}$} & \multirow{2}{*}{$\begin{array}{c}\text { MRSA Staph. } \\
\text { aureus SA4 }\end{array}$} \\
\hline & E15 & E16 & E17 & E13 & Kp1 & Kp8 & Кр9 & Kp5 & & & \\
\hline $4 a$ & $2 \pm 0$ & $2 \pm 0$ & $3 \pm 0$ & $2.2 \pm 0$ & $1.7 \pm 0$ & $2.7 \pm 0$ & $1.9 \pm 0$ & $3.6 \pm 0$ & $2.95 \pm 0.05$ & $2.5 \pm 0$ & $1.85 \pm 0$ \\
\hline $4 \mathrm{~b}$ & 0 & 0 & 0 & 0 & $2.2 \pm 0$ & $1.15 \pm 0.05$ & $1.9 \pm 0.1$ & 0 & $1.85 \pm 0.05$ & $1.85 \pm 0$ & $1.35 \pm 0.05$ \\
\hline $4 \mathrm{c}$ & 0 & 0 & 0 & 0 & $2 \pm 0$ & $1.55 \pm 0.05$ & $2 \pm 0$ & 0 & $2.2 \pm 0.05$ & 0 & 0 \\
\hline $4 d$ & 0 & 0 & 0 & 0 & 0 & $1.15 \pm 0.05$ & 0 & 0 & $1.55 \pm 0.05$ & 0 & 0 \\
\hline $4 e$ & 0 & 0 & 0 & 0 & 0 & 0 & 0 & 0 & 0 & $1.2 \pm 0$ & 0 \\
\hline $7 a$ & $1.2 \pm 0$ & $1.2 \pm 0$ & $\begin{array}{l}1.35 \pm \\
0.05\end{array}$ & 0 & 0 & 0 & 0 & $1.2 \pm 0$ & $1.85 \pm 0.05$ & 0 & 0 \\
\hline $7 \mathrm{~b}$ & $3.1 \pm 0.1$ & 0 & 0 & $\begin{array}{c}2.3 \pm \\
0.1\end{array}$ & 0 & 0 & 0 & 0 & $2.2 \pm 0.05$ & 0 & 0 \\
\hline $7 \mathrm{c}$ & $1.5 \pm 0$ & $1.3 \pm 0$ & $1.5 \pm 0$ & $1.7 \pm 0$ & $1.5 \pm 0$ & $1.05 \pm 0.05$ & $\begin{array}{c}1.25 \pm \\
0.05\end{array}$ & 0 & $2.0 \pm 0.05$ & 0 & 0 \\
\hline $7 \mathrm{~d}$ & 0 & 0 & 0 & 0 & 0 & 0 & 0 & $1.03 \pm 0.05$ & $1.5 \pm 0.05$ & $1.05 \pm 0.0$ & 0 \\
\hline $7 e$ & 0 & 0 & 0 & 0 & 0 & 0 & 0 & $1.15 \pm 0.05$ & $1.8 \pm 0.05$ & $1.15 \pm 0.0$ & $1.8 \pm 0.05$ \\
\hline
\end{tabular}

On the other hand, the latter group with quinoline moiety, compound diphenyl (1-(3-((7-chloroquinolin-4-yl) amino) propyl) piperidin-2-yl) phosphonate (7c) was the most active one against all tested pathogens (Figure 2). A comparison between cyclic $\alpha$-amino phosphonate using triphenyl phosphite group and cyclic $\alpha$-amino phosphonate group bearing quinolone moiety showed that the former one was the most effective than the one bearing quinolone moiety against MDR bacteria. However, substitution 1.3 di amino propane connected with antimicrobial activity. Several studies stated that $\alpha$-amino-phosphonates have antibacterial and antifungal activities regardless of the moiety [19-22].

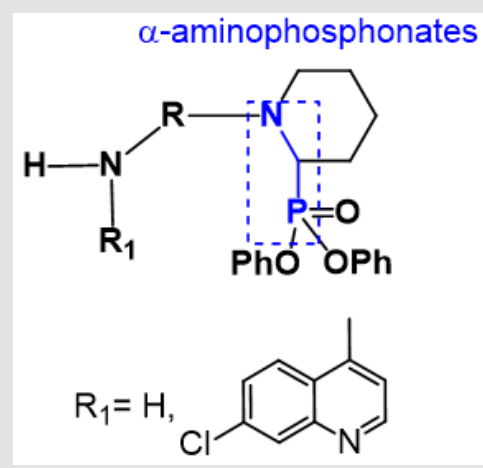

Figure 2: Structures of target a -Aminophosphonates. 


\section{Conclusion}

The formation of novel cyclic $\alpha$-aminophsophonate was installed by three one pot reaction of glutaraldehyde, various diamine derivatives and di or triphenylphsopite in presence of $\mathrm{LiClO}_{4}$ as a catalyst. It was reported that these newly synthesized compounds have potent activity against Klebsiella pneumonia and E. coli bacteria.

\section{Acknowledgment}

We would like to acknowledge financial support by Menoufia University throughout the project number Ib-C2013.

\section{Conflict of Interest}

No conflict of interest.

\section{References}

1. Hamed M, El Gokha A, Ahmed A, Elsayed I, Sabry M, et al. (2015) Synthesis and Antimicrobial Activity of Novel $\alpha$ - Aminophosphonates Bearing Pyrazoloquinoxaline Moiety, International Journal of Pharmaceutical Sciences Review and Research 34(33): 205-213.

2. Danne A, Akolkar S, Deshmukh T, Siddiqui M, Shingate B (2019) One-pot facile synthesis of novel 1,2,3-triazole-appended $\alpha$-aminophosphonates. Journal of the Iranian Chemical Society 16: 953-961.

3. Sreelakshmi P, Maheshwara RN, Santhisudha S, Mohan G, Saichaithanya N, et al. (2019) Nano Sb203 catalyzed green synthesis, cytotoxic activity, and molecular docking study of novel $\alpha$-aminophosphonates 28: 528544.

4. El Boraey Hal, El Gokha AA, El Saye I (2015) Transition metal complexes of $\alpha$-aminophosphonates Part I: synthesis, spectroscopic characterization, and in vitro anticancer activity of copper(II) complexes of $\alpha$-aminophosphonates. Medicinal Chemistry Research 24: 2142-2153.

5. El Gokha AA, Ahmed AAS, Abdelwahed NAM, El Sayed I ET (2016) Synthesis and Antimicrobial Activity of Novel mono- and bis- $\alpha-$ Aminophosphonate Derivatives. International Journal of Pharmaceutical Sciences Review and Research 36(2): 35-39.

6. Xu Y, Yan K, Song B, Xu G, Yang S, et al. (2016) Synthesis and Antiviral Bioactivities of $\alpha$-Aminophosphonates Containing Alkoxyethyl Moieties. Molecules 11(6): 666-676.

7. Maier L, Diel PJ (1994) Phosphorus, Sulfur and Silicon 9: 259.

\section{ISSN: 2574-1241}

DOI: 10.26717/BJSTR.2019.23.003936

Ibrahim El Tantawy El Sayed. Biomed J Sci \& Tech Res

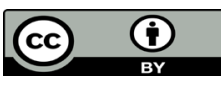

This work is licensed under Creative Commons Attribution 4.0 License

Submission Link: https://biomedres.us/submit-manuscript.php
8. Kafarski P, Lejczak B (1991) Phosphorus, Sulfur and Silicon 63: 193.

9. Treov KD (2006) Chemistry and application of H-phosphonates; Elservier: Amsterdam, Netherlands, pp. 256.

10. Engel R (1977) Chem Rev 77: 349-367.

11. Moonen K, Laureyn W, Stevens CV (2004) Chem Rev 104: 6177-6216.

12. Kafarski P, Lejczak B (2001) Curr Med Chem, Anti-Cancer Agents, 1: 301 312.

13. Kukowska M (2017) Amino acid or peptide conjugates of acridine/ acridone and quinoline/quinolone-containing drugs. A critical examination of their clinical effectiveness within a twenty-year timeframe in antitumor chemotherapy and treatment of infectious diseases. European Journal of Pharmaceutical Sciences 109: 587-615.

14. Vladimir V, Kouznetsov Carlos M, Meléndez Gómez, José Luis Valencia Peña, Leonor Y, et al. (2019) Natural and synthetic quinoline molecules against tropical parasitic pathologies: an analysis of activity and structural evolution for developing new quinoline-based antiprotozoal agents Discovery and Development of Therapeutics from Natural Products Against Neglected Tropical Diseases pp. 87-164.

15. Fernando A Rojas, Vladimir V Kouznetsov (2011) Property-Based Design and Synthesis of New Chloroquine Hybrids via Simple Incorporation of 2-Imino-thiazolidin-4-one or 1H-Pyrrol-2,5-dione Fragments on the 4-Amino-7-chloroquinoline Side Chain J Braz Chem Soc 22(9): 17741781.

16.Xi Feng Zhu, Jing Zhang, Shuo Sun, Yan Chun Guo, Shu Xia Cao, et al. (2017) Synthesis and structure-activity relationships study of $\alpha$-aminophosphonate derivatives containing a quinoline moiety 28(7): Pages 1514-1518.

17. (1993) Glutaraldehyde Cross-Linking, Fast and Slow Modes Timothy J A Johnson.

18. (2008) Reductive Glutaraldehydation of Amine Groups for Identification of Protein N-termini Allison Russo,Nagarajan Chandramouli,Linqi Zhang, and Haiteng Deng, Journal of Proteome Research pp. 4178-4182.

19. Al Shaalan NH (2007) Antimicrobial activity and spectral, magneticand thermal studies of some transition metal complexes of a Schiff base hydrazone containing a quinoline moiety. Molecules 12 (5): 1080-1091.

20. Dibyendu De, Larry D, Bayers, Donald j Krogstad J (1997) Antimalarial: synthesis of 4-aminoquinoline that Circumvent Drug resistance in malaria parasites. heterocyclicchem 34(1): 315.

21. El GokhaAhmed A, Ghanim Ibrahim MS, Abdel MegeedAhmed El S, Elkhabiry Shaban, Ibrahim El Tantawy El Sayed (2013) synthesis and antibacterial activity of novel $\alpha$-aminophosphonates bearing a quinoline moiety 7: 181-189.

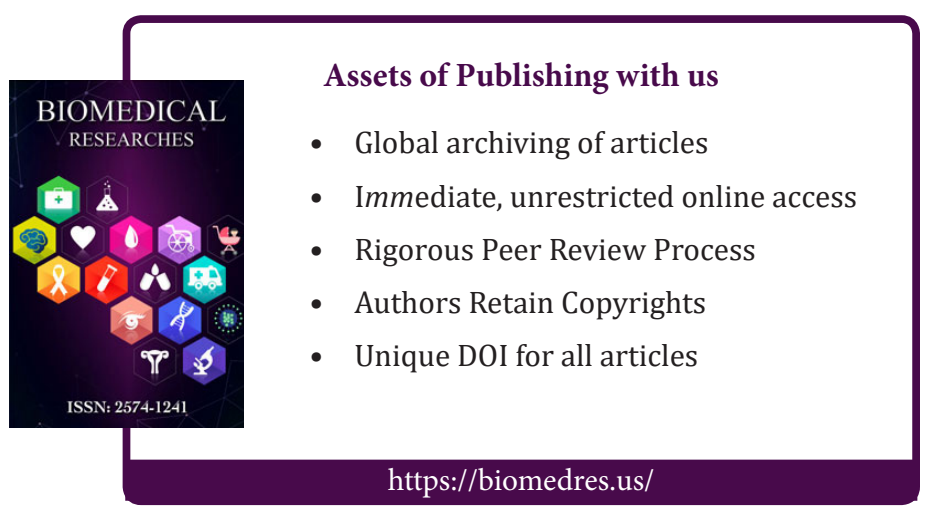

Copyright@ Ibrahim El Tantawy El Sayed | Biomed J Sci \& Tech Res | BJSTR. MS.ID.003936. 